\title{
Tenacibaculum geojense sp. nov., isolated from seawater
}

\author{
Correspondence \\ Jung-Hoon Yoon \\ jhyoon69@skku.edu
}

\author{
So-Jung Kang, ${ }^{1}$ Soo-Young Lee, ${ }^{1}$ Mi-Hwa Lee, ${ }^{1}$ Tae-Kwang Oh ${ }^{1}$ \\ and Jung-Hoon Yoon ${ }^{1,2}$ \\ ${ }^{1}$ Korea Research Institute of Bioscience and Biotechnology (KRIBB), PO Box 115, Yusong, \\ Taejon, Korea \\ ${ }^{2}$ Department of Food Science and Biotechnology, Sungkyunkwan University, Jangan-gu, \\ Suwon, Korea
}

\begin{abstract}
A Gram-negative, non-flagellated, non-spore-forming bacterium, designated YCS- $6^{\top}$, that was motile by gliding, was isolated from seawater on the southern coast of Korea. Strain YCS- ${ }^{\top}$ grew optimally at $30{ }^{\circ} \mathrm{C}$ and with $2 \%(\mathrm{w} / \mathrm{v}) \mathrm{NaCl}$. Phylogenetic analysis based on 16S rRNA gene sequences revealed that strain YCS $-6^{\top}$ fell within the genus Tenacibaculum and was most closely associated with Tenacibaculum litopenaei $\mathrm{B}-\mathrm{I}^{\top}$, with which the isolate exhibited $95.9 \% 16 \mathrm{~S}$ rRNA gene sequence similarity. Sequence similarity between strain YCS $-6^{\top}$ and other members of the genus Tenacibaculum was 93.8-95.7\%. Strain YCS-6 ${ }^{\top}$ contained menaquinone-6 (MK-6) as the predominant respiratory quinone and iso- $\mathrm{C}_{15: 0}$, summed feature 3 (iso- $\mathrm{C}_{15: 0} 2-\mathrm{OH}$ and/or $\left.\mathrm{C}_{16: 1} \omega 7 \mathrm{c}\right)$, iso- $\mathrm{C}_{15: 0} 3-\mathrm{OH}$ and iso- $\mathrm{C}_{15: 1} \mathrm{G}$ as the major fatty acids. The DNA $\mathrm{G}+\mathrm{C}$ content was $32.7 \mathrm{~mol} \%$. Differential phenotypic properties and phylogenetic distinctiveness distinguished strain YCS $-6^{\top}$ from all other members of the genus Tenacibaculum. On the basis of our phenotypic, chemotaxonomic and phylogenetic data, strain YCS $-6^{\top}$ is considered to represent a novel species of the genus Tenacibaculum, for which the name Tenacibaculum geojense sp. nov. is proposed. The type strain is YCS $-6^{\top}\left(=\right.$ KCTC $23423^{\top}=$ CCUG $\left.60527^{\top}\right)$.
\end{abstract}

The genus Tenacibaculum, a member of the family Flavobacteriaceae, phylum Bacteroidetes (Bernardet \& Nakagawa, 2006), was established by Suzuki et al. (2001) with the reclassification of two bacterial species previously allocated to the genus Flexibacter and the description of two novel species. At the time of writing, the genus Tenacibaculum comprises 15 species with validly published names (Euzéby, 1997). All members of the genus have been isolated from marine environments and marine organisms (Suzuki et al., 2001; Frette et al., 2004; Yoon et al., 2005; Sheu et al., 2007; Heindl et al., 2008; Wang et al., 2008; Lee et al., 2009). In this study, we describe a bacterial strain, designated YCS $-6^{\mathrm{T}}$, which was isolated from seawater on the southern coast of Korea and found to be phylogenetically affiliated with the genus Tenacibaculum on the basis of comparative 16S rRNA gene sequence analysis.

Strain YCS- $6^{\mathrm{T}}$ was isolated by the dilution-plating technique using marine agar 2216 (MA; Difco) at $25^{\circ} \mathrm{C}$. Tenacibaculum litopenaei $\mathrm{LMG} 23706^{\mathrm{T}}$ was used as a reference strain for phenotypic characterization and fatty acid analysis. The morphological, physiological and biochemical characteristics of strain YCS- $6^{\mathrm{T}}$ were investigated after routine

The GenBank/EMBL/DDBJ accession number for the 16S rRNA gene

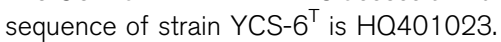

cultivation on MA at $30{ }^{\circ} \mathrm{C}$. Cell morphology was examined by light microscopy (E600; Nikon) and transmission electron microscopy (CM-20; Philips). Flagellation was assessed by transmission electron microscopy using cells from an exponentially growing culture on MA. For this purpose, the cells were negatively stained with $1 \%(\mathrm{w} / \mathrm{v})$ phosphotungstic acid and the grids were examined after being air-dried. Gliding motility was investigated as described by Bowman (2000). The Gram reaction was determined using the bioMérieux Gram-stain kit, according to the manufacturer's instructions. Growth with $0,0.5,1.0$, 2.0 and $3.0 \%(\mathrm{w} / \mathrm{v}) \mathrm{NaCl}$ was investigated using trypticase soy broth prepared according to the formula of the Difco medium except that $\mathrm{NaCl}$ was replaced with $0.45 \%(\mathrm{w} / \mathrm{v})$ $\mathrm{MgCl}_{2} \cdot 6 \mathrm{H}_{2} \mathrm{O}$ or $0.06 \%$ (w/v) KCl. Growth with $2.0-10.0 \%$ $(\mathrm{w} / \mathrm{v}) \mathrm{NaCl}$ (in increments of $1.0 \%$ ) was measured in marine broth 2216 (MB; Difco). Growth at $10-45{ }^{\circ} \mathrm{C}$ (in increments of $5{ }^{\circ} \mathrm{C}$ ), 28 and $37{ }^{\circ} \mathrm{C}$ was measured on MA. Growth at $\mathrm{pH} 4.5-9.5$ (in increments of $0.5 \mathrm{pH}$ units) was measured in $\mathrm{MB}$ using sodium acetate/acetic acid and $\mathrm{Na}_{2} \mathrm{CO}_{3}$ to adjust the $\mathrm{pH}$. The $\mathrm{pH}$ was verified after autoclaving. Growth under anaerobic conditions was determined by incubation in a Forma anaerobic chamber on MA and on MA supplemented with potassium nitrate $(0.1 \%, w / v)$, both of which had been prepared anaerobically 
under a nitrogen atmosphere. Catalase and oxidase activities were determined as described by Cowan \& Steel (1965). Hydrolysis of casein, starch, hypoxanthine, tyrosine and xanthine was tested on MA, using the substrate concentrations described by Cowan \& Steel (1965). Hydrolysis of aesculin, gelatin, Tweens 20,40,60 and 80 and urea and reduction of nitrate were investigated as described by Lányí (1987) with the modification that media were prepared with artificial seawater [containing (per l distilled water) $23.6 \mathrm{~g}$ $\mathrm{NaCl}, 0.64 \mathrm{~g} \mathrm{KCl}, 4.53 \mathrm{~g} \mathrm{MgCl}_{2} \cdot 6 \mathrm{H}_{2} \mathrm{O}, 5.94 \mathrm{~g} \mathrm{MgSO}_{4} \cdot 7 \mathrm{H}_{2} \mathrm{O}$ and $1.3 \mathrm{~g} \mathrm{CaCl}_{2} \cdot 2 \mathrm{H}_{2} \mathrm{O}$; Bruns et al., 2001]. $\mathrm{H}_{2} \mathrm{~S}$ production was tested as described by Bruns et al. (2001). The presence of flexirubin-type pigments was investigated as described by Reichenbach (1992). Acid production from carbohydrates was determined as described by Leifson (1963). Susceptibility to antibiotics was tested on MA using antibiotic discs (Advantec) containing the following ( $\mu \mathrm{g}$ per disc unless otherwise stated): polymyxin B (100 U), streptomycin (50), penicillin G (20 U), chloramphenicol (100), ampicillin (10), cephalothin (30), gentamicin (30), novobiocin (5), tetracycline (30), kanamycin (30), lincomycin (15), oleandomycin (15), neomycin (30) and carbenicillin (100). Other physiological and biochemical tests were performed with the API 20 $\mathrm{E}$ and API ZYM systems (bioMérieux) at $30{ }^{\circ} \mathrm{C}$ for 2 days and $8 \mathrm{~h}$, respectively. The morphological, cultural, physiological and biochemical characteristics of strain YCS- $6^{\mathrm{T}}$ are given in the species description and Table 1 . Strain ${\text { YCS }-6^{T} \text { was }}^{T}$ distinguishable from its closest phylogenetic neighbour, $T$. litopenaei $\mathrm{LMG} 23706^{\mathrm{T}}$, by differences in several phenotypic characteristics, most of which were determined under the same conditions and methods (Table 1).

Cell biomass of strain YCS- $6^{\mathrm{T}}$ for DNA extraction and isoprenoid quinone analysis was obtained from cultures grown for 2 days in $\mathrm{MB}$ at $30{ }^{\circ} \mathrm{C}$. Chromosomal DNA was isolated and purified according to the method described previously (Yoon et al., 1996), with the exception that RNase T1 was used in combination with RNase A to minimize contamination with RNA. The $16 \mathrm{~S}$ rRNA gene was amplified by PCR using two universal primers as described previously (Yoon et al., 1998). Sequencing of the amplified 16S rRNA gene and phylogenetic analysis were performed as described by Yoon et al. (2003). The almost-complete 16S rRNA gene sequence of strain YCS $-6^{\mathrm{T}}$ determined in this study comprised 1442 nt (approx. $96 \%$ of the Escherichia coli $16 \mathrm{~S}$ rRNA sequence). In the neighbour-joining phylogenetic tree, strain YCS $-6^{\mathrm{T}}$ fell within the genus Tenacibaculum and was most closely associated with $T$. litopenaei $\mathrm{B}^{\mathrm{T}} \mathrm{I}^{\mathrm{T}}(97.6 \%$ bootstrap support), and this relationship was also recovered in trees reconstructed using the maximum-likelihood and maximum-parsimony algorithms (Fig. 1). Strain YCS-6 ${ }^{\mathrm{T}}$ exhibited $95.9 \% 16 \mathrm{~S}$ rRNA gene sequence similarity to $T$. litopenaei $\mathrm{B}-\mathrm{I}^{\mathrm{T}}$, $93.8-95.7 \%$ to other members of the genus Tenacibaculum and $<93.0 \%$ to the other taxa used in the phylogenetic analysis.

Isoprenoid quinones were extracted according to the method of Komagata \& Suzuki (1987) and analysed using reversed-phase HPLC and a YMC ODS-A $(250 \times 4.6 \mathrm{~mm})$
Table 1. Differential phenotypic characteristics of strain YCS$6^{\top}$ and its closest phylogenetic neighbour in the genus Tenacibaculum

Data were taken from this study unless otherwise indicated. Both strains are Gram-negative rods and positive for gliding motility*, hydrolysis of gelatin ${ }^{\star}$ and $\operatorname{starch}^{\star}$, activities of alkaline phosphatase, leucine arylamidase, valine arylamidase, acid phosphatase and naphthol-AS-BI-phosphohydrolase and susceptibility to chloramphenicol, lincomycin, novobiocin, oleandomycin and tetracycline. Both strains are negative for flagellation ${ }^{\star}$, production of flexirubin-type pigments $^{\star}$, nitrate reduction ${ }^{\star}$, production of $\mathrm{H}_{2} \mathrm{~S}^{*}$ and indole ${ }^{\star}$, hydrolysis of urea ${ }^{\star}$, acid production from L-arabinose, cellobiose, Dfructose, myo-inositol, lactose, D-mannitol, D-mannose, melezitose, melibiose, raffinose, L-rhamnose, D-ribose, D-sorbitol, trehalose and $\mathrm{D}$-xylose, activities of lipase (C14), cystine arylamidase, trypsin, $\alpha$-chymotrypsin, $\alpha$ - and $\beta$-galactosidases, $\beta$-glucuronidase, $\alpha$ - and $\beta$-glucosidases, $N$-acetyl- $\beta$-glucosaminidase, $\alpha$-mannosidase and $\alpha$ fucosidase and susceptibility to ampicillin, gentamicin, kanamycin, neomycin, penicillin G, polymyxin B and streptomycin. +, Positive; $\mathrm{w}$, weakly positive; -, negative.

\begin{tabular}{|c|c|c|}
\hline Characteristic & YCS- $6^{T}$ & $\begin{array}{l}\text { T. litopenae } \\
\text { LMG } 23706^{\mathrm{T}}\end{array}$ \\
\hline Catalase & + & $-{ }^{\star}$ \\
\hline Oxidase & - & $+^{*}$ \\
\hline \multicolumn{3}{|l|}{ Hydrolysis of: } \\
\hline Aesculin & + & $-{ }^{\star}$ \\
\hline Tween 80 & + & $-{ }^{\star}$ \\
\hline \multicolumn{3}{|l|}{ Acid production from: } \\
\hline D-Galactose & - & + \\
\hline D-Glucose & $\mathrm{w}$ & - \\
\hline Maltose & $\mathrm{w}$ & + \\
\hline Sucrose & + & - \\
\hline \multicolumn{3}{|l|}{ Enzyme activity } \\
\hline Esterase (C4) & + & - \\
\hline Esterase lipase (C8) & + & - \\
\hline \multicolumn{3}{|l|}{ Susceptibility to: } \\
\hline Carbenicillin & + & - \\
\hline Cephalothin & + & - \\
\hline DNA G $+C$ content $(\mathrm{mol} \%)$ & 32.7 & $35.2^{\star}$ \\
\hline
\end{tabular}

${ }^{*}$ Data for T. litopenaei $\mathrm{B}-\mathrm{I}^{\mathrm{T}}$ taken from Sheu et al. (2007).

column. The predominant isoprenoid quinone detected in strain YCS- $6^{\mathrm{T}}$ was menaquinone-6 (MK-6), which is in line with all members of the family Flavobacteriaceae (Bernardet \& Nakagawa, 2006). For fatty acid methyl ester analysis, cell mass of strain YCS- $6^{\mathrm{T}}$ and T. litopenaei LMG $23706^{\mathrm{T}}$ was harvested from MA after incubation for 2 days at $30{ }^{\circ} \mathrm{C}$. Fatty acids were saponified, methylated and extracted using the standard protocol of the Sherlock Microbial Identification System, version 4.0 (MIDI). The fatty acid methyl esters were analysed by GC (model 6890; Hewlett Packard) and identified using the TSBA40 database of the Microbial Identification System (Sasser, 1990). The cellular fatty acid compositions of strain YCS- $6^{\mathrm{T}}$ and T. litopenaei LMG $23706^{\mathrm{T}}$ are shown in Table 2. The major 


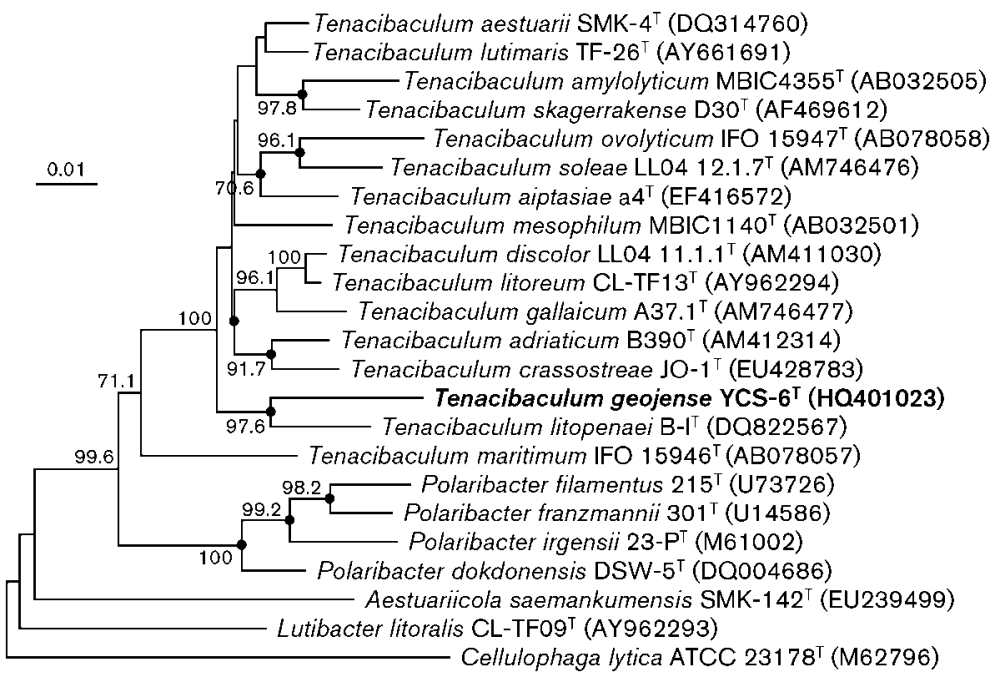

Fig. 1. Neighbour-joining phylogenetic tree based on 16S rRNA gene sequences showing the positions of strain $\mathrm{YCS}-6^{\top}$, members of the genus Tenacibaculum and members of some other related genera. Bootstrap values $(>70 \%)$ based on 1000 replications are shown at branch nodes. Filled circles indicate that the corresponding nodes were also recovered in trees generated with the maximum-likelihood and maximum-parsimony algorithms. Cellulophaga lytica ATCC $23178^{\top}$ was used as an outgroup. Bar, 0.01 substitutions per nucleotide position.

Table 2. Cellular fatty acid compositions of strain YCS $-6^{\top}$ and its closest phylogenetic neighbour in the genus Tenacibaculum

Data were obtained in this study. Values are percentages of total fatty acids; fatty acids that represented $<0.5 \%$ in both strains are not shown. tr, Trace $(<0.5 \%)$; - , not detected; ECL, equivalent chain-length.

\begin{tabular}{|c|c|c|}
\hline Fatty acid & $\mathrm{YCS}^{-6^{\mathrm{T}}}$ & T. litopenaei LMG $23706^{\mathrm{T}}$ \\
\hline \multicolumn{3}{|l|}{ Straight-chain } \\
\hline $\mathrm{C}_{15: 0}$ & 2.3 & 1.8 \\
\hline $\mathrm{C}_{16: 0}$ & $\operatorname{tr}$ & 1.0 \\
\hline \multicolumn{3}{|l|}{ Unsaturated } \\
\hline $\mathrm{C}_{15: 1} \omega 6 c$ & 2.5 & 0.8 \\
\hline $\mathrm{C}_{17: 1} \omega 6 c$ & 0.6 & 1.0 \\
\hline \multicolumn{3}{|l|}{ Branched } \\
\hline iso- $\mathrm{C}_{13: 0}$ & 1.5 & $\operatorname{tr}$ \\
\hline iso- $\mathrm{C}_{14: 0}$ & 1.5 & $\operatorname{tr}$ \\
\hline iso- $\mathrm{C}_{15: 1} \mathrm{G}^{*}$ & 10.2 & 3.0 \\
\hline iso- $\mathrm{C}_{15: 0}$ & 23.5 & 13.1 \\
\hline anteiso- $\mathrm{C}_{15: 0}$ & 0.6 & $\operatorname{tr}$ \\
\hline iso- $\mathrm{C}_{16: 0}$ & 1.2 & 1.1 \\
\hline iso- $\mathrm{C}_{16: 1} \mathrm{H}^{*}$ & 1.1 & - \\
\hline iso- $\mathrm{C}_{17: 1} \omega 9 c$ & 0.9 & 0.9 \\
\hline \multicolumn{3}{|l|}{ Hydroxy } \\
\hline $\mathrm{C}_{15: 0} 2-\mathrm{OH}$ & $\operatorname{tr}$ & 1.1 \\
\hline $\mathrm{C}_{15: 0} 3-\mathrm{OH}$ & 2.5 & 3.6 \\
\hline iso- $\mathrm{C}_{15: 0} 3-\mathrm{OH}$ & 10.5 & 7.2 \\
\hline $\mathrm{C}_{16: 0} 3-\mathrm{OH}$ & 1.0 & 7.4 \\
\hline iso- $\mathrm{C}_{16: 0} 3-\mathrm{OH}$ & 8.4 & 5.6 \\
\hline $\mathrm{C}_{17: 0} 2-\mathrm{OH}$ & $\operatorname{tr}$ & 0.8 \\
\hline $\mathrm{C}_{17: 0} 3-\mathrm{OH}$ & $\operatorname{tr}$ & 1.3 \\
\hline iso- $\mathrm{C}_{17: 0} 3-\mathrm{OH}$ & 9.9 & 19.0 \\
\hline \multicolumn{3}{|l|}{ Summed features $\dagger$} \\
\hline 2 & - & 1.1 \\
\hline 3 & 16.4 & 25.8 \\
\hline \multicolumn{3}{|c|}{ Unknown fatty acids } \\
\hline ECL 13.565 & 0.7 & 0.8 \\
\hline ECL 16.582 & 0.6 & 0.8 \\
\hline
\end{tabular}

${ }^{*}$ The position of the double bond indicated by the capital letter is unknown.

$\uparrow$ Summed features represent groups of two or three fatty acids that cannot be separated by the Microbial Identification System. Summed feature 2 consisted of $\mathrm{C}_{14: 0} 3-\mathrm{OH}$ and/or iso- $\mathrm{C}_{16: 1}$ I. Summed feature 3 consisted of iso- $\mathrm{C}_{15: 0} 2-\mathrm{OH}$ and/or $\mathrm{C}_{16: 1} \omega 7 c$. 
fatty acids $(>10 \%$ of the total $)$ in strain $\mathrm{YCS}-6^{\mathrm{T}}$ were iso- $\mathrm{C}_{15: 0}$, summed feature 3 (iso- $\mathrm{C}_{15: 0} 2-\mathrm{OH}$ and/or $\left.\mathrm{C}_{16: 1} \omega 7 c\right)$, iso- $\mathrm{C}_{15: 0} 3-\mathrm{OH}$ and iso- $\mathrm{C}_{15: 1} \mathrm{G}$. The fatty acid composition of strain YCS- $6^{\mathrm{T}}$ was similar to that of $T$. litopenaei LMG $23706^{\mathrm{T}}$, but the two strains could be differentiated by differences in the proportions of some fatty acids. The fatty acid composition of strain YCS $-6^{\mathrm{T}}$ was also similar to those of other members of the genus Tenacibaculum (Lee et al., 2009). The DNA G + C content was determined by the method of Tamaoka \& Komagata (1984) with the modification that DNA was hydrolysed and the resultant nucleotides were analysed by reversedphase HPLC. The DNA G + C content of strain YCS $-6^{\mathrm{T}}$ was $32.7 \mathrm{~mol} \%$, which is in the range reported for members of the genus Tenacibaculum (29.8-35.2 mol\%; Lee et al., 2009). The chemotaxonomic data supported the phylogenetic inference that strain YCS $-6^{\mathrm{T}}$ belonged to the genus Tenacibaculum (Suzuki et al., 2001; Frette et al., 2004; Yoon et al., 2005; Choi et al., 2006; Jung et al., 2006; Sheu et al., 2007; Heindl et al., 2008; Piñeiro-Vidal et al., 2008; Wang et al., 2008; Lee et al., 2009).

The phylogenetic distinctiveness of strain YCS $-6^{\mathrm{T}}$, together with the differential phenotypic properties, is sufficient to show that this strain is separate from all other members of the genus Tenacibaculum (Stackebrandt \& Goebel, 1994). Therefore, strain YCS $-6^{\mathrm{T}}$ is considered to represent a novel species, for which the name Tenacibaculum geojense sp. nov. is proposed.

\section{Description of Tenacibaculum geojense sp. nov.}

Tenacibaculum geojense (ge.o.jen'se. N.L. neut. adj. geojense of Geoje, Korea, from where the type strain was isolated).

Cells are Gram-negative, non-spore-forming, non-flagellated rods (0.2-0.4 $\mu \mathrm{m}$ wide and 1.0-9.0 $\mu \mathrm{m}$ long; a few cells longer than $10 \mu \mathrm{m}$ are also observed). Motile by gliding. Degenerative spherical cells are observed in ageing cultures. Flexirubin-type pigments are not produced. Colonies on MA are circular to irregular, flat, smooth, glistening, yellow, non-adherent and $2.0-5.0 \mathrm{~mm}$ in diameter after incubation for 2 days at $30{ }^{\circ} \mathrm{C}$. Grows at $15-40{ }^{\circ} \mathrm{C}$ (optimum $30{ }^{\circ} \mathrm{C}$ ), but not at 10 or $45{ }^{\circ} \mathrm{C}$, at pH 5.5 (optimum pH 7.0-8.0), but not at $\mathrm{pH} 5.0$, and with $0-7.0 \%(\mathrm{w} / \mathrm{v}) \mathrm{NaCl}$ (optimum $2 \%$ $\mathrm{NaCl}) . \mathrm{Mg}^{2+}$ ions are required for growth. Growth does not occur under anaerobic conditions on MA or on MA supplemented with nitrate. Catalase-positive and oxidasenegative. $\mathrm{H}_{2} \mathrm{~S}$ is not produced. Nitrate is not reduced. Casein, tyrosine and Tweens 20, 40 and 60 are hydrolysed, but hypoxanthine and xanthine are not. The predominant menaquinone is MK-6. The major fatty acids $(>10 \%$ of total) are iso- $\mathrm{C}_{15: 0}$, summed feature 3 (iso- $\mathrm{C}_{15: 0}$ 2-OH and/ or $\mathrm{C}_{16: 1} \omega 7 c$ ), iso- $\mathrm{C}_{15: 0} 3-\mathrm{OH}$ and iso- $\mathrm{C}_{15: 1} \mathrm{G}$. Other phenotypic properties are shown in Table 1 . The DNA G + C content of the type strain is $32.7 \mathrm{~mol} \%$ (HPLC).

The type strain, YCS $-6^{\mathrm{T}} \quad\left(=\mathrm{KCTC} 23423^{\mathrm{T}}=\mathrm{CCUG}\right.$ $60527^{\mathrm{T}}$ ), was isolated from seawater collected from the South Sea near the city of Geoje, Korea.

\section{Acknowledgements}

This work was supported by the 21C Frontier Program of Microbial Genomics and Applications (grant no. 11-2008-00-002-00) and the Program for Collection, Management and Utilization of Biological Resources (grant no. M10867010003) from the Ministry of Education, Science and Technology (MEST), Republic of Korea.

\section{References}

Bernardet, J.-F. \& Nakagawa, Y. (2006). An introduction to the family Flavobacteriaceae. In The Prokaryotes: a Handbook on the Biology of Bacteria, 3rd edn, vol. 7, pp. 455-480. Edited by M. Dworkin, S. Falkow, E. Rosenberg, K. H. Schleifer \& E. Stackebrandt. New York: Springer.

Bowman, J. P. (2000). Description of Cellulophaga algicola sp. nov., isolated from the surfaces of Antarctic algae, and reclassification of Cytophaga uliginosa (ZoBell and Upham 1944) Reichenbach 1989 as Cellulophaga uliginosa comb. nov. Int J Syst Evol Microbiol 50, 18611868.

Bruns, A., Rohde, M. \& Berthe-Corti, L. (2001). Muricauda ruestringensis gen. nov., sp. nov., a facultatively anaerobic, appendaged bacterium from German North Sea intertidal sediment. Int $J$ Syst Evol Microbiol 51, 1997-2006.

Choi, D. H., Kim, Y.-G., Hwang, C. Y., Yi, H., Chun, J. \& Cho, B. C. (2006). Tenacibaculum litoreum sp. nov., isolated from tidal flat sediment. Int J Syst Evol Microbiol 56, 635-640.

Cowan, S. T. \& Steel, K. J. (1965). Manual for the Identification of Medical Bacteria. London: Cambridge University Press.

Euzéby, J. P. (1997). List of Bacterial Names with Standing in Nomenclature: a folder available on the Internet. Int J Syst Bacteriol 47, 590-592.

Frette, L., Jørgensen, N. O. G., Irming, H. \& Kroer, N. (2004). Tenacibaculum skagerrakense sp. nov., a marine bacterium isolated from the pelagic zone in Skagerrak, Denmark. Int J Syst Evol Microbiol 54, 519-524.

Heindl, H., Wiese, J. \& Imhoff, J. F. (2008). Tenacibaculum adriaticum sp. nov., from a bryozoan in the Adriatic Sea. Int J Syst Evol Microbiol 58, 542-547.

Jung, S.-Y., Oh, T.-K. \& Yoon, J.-H. (2006). Tenacibaculum aestuarii sp. nov., isolated from a tidal flat sediment in Korea. Int J Syst Evol Microbiol 56, 1577-1581.

Komagata, K. \& Suzuki, K. (1987). Lipid and cell-wall analysis in bacterial systematics. Methods Microbiol 19, 161-207.

Lányí, B. (1987). Classical and rapid identification methods for medically important bacteria. Methods Microbiol 19, 1-67.

Lee, Y. S., Baik, K. S., Park, S. Y., Kim, E. M., Lee, D.-H., Kahng, H.-Y., Jeon, C. O. \& Jung, J. S. (2009). Tenacibaculum crassostreae sp. nov., isolated from the Pacific oyster, Crassostrea gigas. Int J Syst Evol Microbiol 59, 1609-1614.

Leifson, E. (1963). Determination of carbohydrate metabolism of marine bacteria. J Bacteriol 85, 1183-1184.

Piñeiro-Vidal, M., Riaza, A. \& Santos, Y. (2008). Tenacibaculum discolor sp. nov. and Tenacibaculum gallaicum sp. nov., isolated from sole (Solea senegalensis) and turbot (Psetta maxima) culture systems. Int J Syst Evol Microbiol 58, 21-25.

Reichenbach, H. (1992). The order Cytophagales. In The Prokaryotes, 2nd edn, vol. 4, pp. 3631-3675. Edited by A. Balows, H. G. Trüper, M. Dworkin, W. Harder \& K. H. Schleifer. New York: Springer.

Sasser, M. (1990). Identification of bacteria by gas chromatography of cellular fatty acids, MIDI Technical Note 101. Newark, DE: MIDI Inc. 
Sheu, S.-Y., Lin, K.-Y., Chou, J.-H., Chang, P.-S., Arun, A. B., Young, C.-C. \& Chen, W.-M. (2007). Tenacibaculum litopenaei sp. nov., isolated from a shrimp mariculture pond. Int J Syst Evol Microbiol 57, 1148-1153.

Stackebrandt, E. \& Goebel, B. M. (1994). Taxonomic note: a place for DNA-DNA reassociation and $16 \mathrm{~S}$ rRNA sequence analysis in the present species definition in bacteriology. Int J Syst Bacteriol 44, 846-849.

Suzuki, M., Nakagawa, Y., Harayama, S. \& Yamamoto, S. (2001). Phylogenetic analysis and taxonomic study of marine Cytophaga-like bacteria: proposal for Tenacibaculum gen. nov. with Tenacibaculum maritimum comb. nov. and Tenacibaculum ovolyticum comb. nov., and description of Tenacibaculum mesophilum sp. nov. and Tenacibaculum amylolyticum sp. nov. Int J Syst Evol Microbiol 51, 1639-1652.

Tamaoka, J. \& Komagata, K. (1984). Determination of DNA base composition by reversed-phase high-performance liquid chromatography. FEMS Microbiol Lett 25, 125-128.
Wang, J.-T., Chou, Y.-J., Chou, J.-H., Chen, C. A. \& Chen, W.-M. (2008). Tenacibaculum aiptasiae sp. nov., isolated from a sea anemone Aiptasia pulchella. Int J Syst Evol Microbiol 58, 761-766.

Yoon, J.-H., Kim, H., Kim, S.-B., Kim, H.-J., Kim, W. Y., Lee, S. T., Goodfellow, M. \& Park, Y.-H. (1996). Identification of Saccharomonospora strains by the use of genomic DNA fragments and rRNA gene probes. Int J Syst Bacteriol 46, 502-505.

Yoon, J.-H., Lee, S. T. \& Park, Y.-H. (1998). Inter- and intraspecific phylogenetic analysis of the genus Nocardioides and related taxa based on 16S rDNA sequences. Int J Syst Bacteriol 48, 187-194.

Yoon, J.-H., Kim, I.-G., Shin, D.-Y., Kang, K. H. \& Park, Y.-H. (2003). Microbulbifer salipaludis sp. nov., a moderate halophile isolated from a Korean salt marsh. Int J Syst Evol Microbiol 53, 53-57.

Yoon, J.-H., Kang, S.-J. \& Oh, T.-K. (2005). Tenacibaculum lutimaris sp. nov., isolated from a tidal flat in the Yellow Sea, Korea. Int J Syst Evol Microbiol 55, 793-798. 